\title{
Analisis Kualitas Air Sumur Di Desa Candikuning Kecamatan Baturiti
}

\section{Dewa Made Atmaja}

Masuk: 04092018 / Diterima: 28112018 / Dipublikasi: 31122018

C 2018 Fakultas Hukum dan IImu Sosial UNDIKSHA dan IGI

\begin{abstract}
This research is aimed to analyze pH. Temperate, water color, TDS (total dissolved solid) and turbidity of well water at Candikuning villages, Tabanan regency. The subject of research is well water at Candikuning villages, and the object of the research is $\mathrm{pH}$, temperate, water color, TDS and turbidity of well water. The result of the research showed color concentration, TDS, and turbidity of well water 7,8. 310C. $30.4 \mathrm{TCU} ; 221.7 \mathrm{mg} / \mathrm{L}$; and $6.1 \mathrm{NTU}$ scale respectively. Color and turbidity of water is over limited maximal concentration that permitted agree with a health minister of RI decree of No. 907/MENKES/SK/VII/2002. On the other hand, TDS concentration is under limited maximum concentration that permitted. It is showed that well water at orchard, Candikuning villages, urgent to obtain of consideration for direct consumption.
\end{abstract}

Keywords: Well Water; Water Quality

Abstrak Penelitian ini bertujuan untuk menganalisis pH, suhu warna, TDS (Total Dissolved Solid), dan kekeruhan air pada air sumur di Desa Candikuning Kabupaten Tabanan, Subjek penelitian ini adalah air sumur di Desa Candikuning, dan objek dalam penelitian ini adalah pH, suhu, warna, TDS dan kekeruhan dalam air sumur tersebut. Hasil penelitian menunjukkan bahwa kadar warna, TDS, dan kekeruhan air sumur secara berturut-turut adalah 7,8, 310C, 30,4 Skala TCU; 221,7 mg/L; 6,1 Skala NTU. Warna dan kekeruhan berada di atas batas kadar maksimal yang diperbolehkan sesuai dengan Keputusan Menteri Kesehatan RI No. 907/MENKES/SK/VII/2002, sedangkan kadar TDS masih berada di bawah batas kadar maksimal yang diperbolehkan. Hal ini menunjukkan bahwa air sumur di Desa Candikuning perlu mendapat pertimbangan untuk dikonsumsi secara langsung.

Kata kunci: Air Sumur; Kualitas Air

\section{Pendahuluan}

Air merupakan kebutuhan dasar bagi manusia. Bagi manusia, air selain diperlukan untuk keperluan rumah tangga, juga digunakan untuk pertanian, industri, transportasi dan pariwisata. Dengan demikian semakin naik pertumbuhan penduduk, maka semakin naik pula laju pemanfaatan sumber-sumber air. Hal ini menyebabkan beban pengotor air juga bertambah cepat sesuai dengan laju partumbuhan penduduk. Sebagai akibatnya sumber air tawar dan air bersih saat ini menjadi langka. Air sebagai sumber daya alam yang amat penting nilainya bagi kehidupan manusia hendaknya juga harus dimanfaatkan

Dewa Made Atmaja

Jurusan D3 Survei dan Pemetaan Fakultas Hukum dan IImu Sosial Universitas Pendidikan Ganesha

dewamade1027@gmail.com secara hemat tanpa merusak tata lingkungan hidup manusia, sebagai salah satu bagian dari sumber daya alam, air di muka bumi berbeda-beda menurut ruang dan waktu. Banyak daerah yang mempunyai potensi air yang cukup, tetapi tidak jarang dijumpai daerah-daerah yang mempunyai potensi air yang kecil, bahkan dalam waktu-waktu tertentu mengalami kekurangan air.

Meningkatnya beban pengotor air berakibat pada kesulitan masyarakat mendapatkan sumber air bersih untuk kebutuhan rumah tangga, serta untuk keperluan air minum. Untuk mengatasi hal ini pemerintah daerah khususnya Pemerintah Kabupaten Tabanan telah mengupayakan pelayanan persediaan air bersih yaitu melalui Perusahaan Distribusi Air Minum (PDAM), sehingga diharapkan dengan adanya PDAM ini kebutuhan 
masyarakat akan air bersih dapat dipenuhi. Pada kenyataanya tidak semua masyarakat mau memanfaatkan pelayanan PDAM dalam memenuhi kebutuhan akan air bersih. Seperti halnya masyarakat Desa Candikuning yang masih memanfaatkan air sumur gali untuk memenuhi kebutuhan sehari-hari, terutama untuk air minum dan digunakan untuk mandi.

Desa Candikuning merupakan salah satu desa yang terdapat di Kecamatan Baturiti, Kabupaten Tabanan. Desa Candikuning memilki ketinggian dari permukaan air laut 750-1.200 meter, luas wilayah 15,83 Km2 yang dihuni oleh 11.200 orang (jiwa). Masyarakat Desa Candikuning yang memiliki luas wilayah $12,5 \mathrm{Km} 2$ dan dihuni oleh 7.127 jiwa (Data Statistik Desa Candikuning), masih ada beberapa masyarakat yang memanfaatkan air sumur sebagai sumber air untuk memenuhi kebutuhan air seharisehari seperti memasak, mandi, mencuci, bahkan untuk air minum. Sumur yang terdapat di Desa Candikuning sebanyak 5 sumur tetapi yang sering digunakan sebanyak 3 sumur karena 2 sumur lainnya sudah tidak layak digunakan jika dilihat dari warna dan bau dari air sumur tersebut. Sumur yang terdapat di Desa Candikuning memiliki kedalaman 5-7 meter. Kondisi sumur di daerah tersebut kurang memperhatikan syarat lokasi dan kontruksi di dalam pembuatannya. Jarak antara sumur dengan sumber pencemar hanya berjarak sekitar 1-2 meter, selain dekatnya dengan sumber pencemar yaitu sungai, septic tank, dan kandang babi, kondisi fisik sumur tersebut masih jauh dari layak untuk dijadikan sebagai sumur yang sehat. Sumur yang ada, tidak berlantai semen, walaupaun ada, kondisinya sudah rusak (lantainya retakretak). Bagian dalam sumur juga tidak diberi dinding, sehingga kedua sumur tersebut yang bagian dindingnya ditumbuhi oleh tanaman seperti paku, dan jenis tanaman yang biasa hidup di tempat yang lembab, sehingga kemungkinan besar air sumur akan tercemar. Selain itu, kondisi lingkungan sangat kotor, banyak terdapat sampah-sampah baik itu organik maupun anorganik yang berserakan.

Apabila musim hujan, kondisi sumur di Dusun Desa Candikuning akan semakin buruk, apalagi sumur tersebut sangat dekat dengan air limbah dimana limbah tersebut sering digunakan penduduk untuk menyiram tanaman, dan tempat untuk buang sampah, sehingga kemungkinan besar sumur akan terkontaminasi oleh pengotor-pengotor tersebut dengan adanya perembesan melalui celah-celah dinding sumur ataupun perserapan oleh tanah dan akan merembes ke dalam sumur. Hal tersebut akan menyebabkan adanya perubahan warna, padatan total terlarut dan kekeruhan pada sumur. Berdasarkan informasi dari masyarakat bahwa bila musim hujan warna air sumur berubah menjadi warna coklat.

Air yang keruh, apabila air tersebut mengandung begitu banyak yang tersuspensi sehingga memberikan warna atau rupa yang belumpur dan kotor. Bahan-bahan yang menyebabkan kekeruhan meliputi : tanah liat, lumpur, bahan-bahan organik yang tersebar secara baik dan partikel-partikel kecil yang tersuspensi lainnya. Kekeruhan tidak merupakan sifat dari air yang membahayakan, tetapi ia menjadi tidak disenangi karena rupanya. Untuk membuat air memuaskan untuk penggunaan rumah tangga, usaha penghilangan secara hampir sempurna bahan-bahan yang menyebabkan kekeruhan, adalah penting (Sutrisno, 1991). Untuk mengantisipasi hal tersebut, maka pemerintah telah mengeluarkan KEPMENKES NO. 907/MENKES/SK/VII/2002 tentang nilai parameter kualitas air minum. Dalam KEPMENKES tersebut mencakup 
parameter fisika yang diantaranya parameter warna, TDS, dan Kekeruhan.

Berdasarkan uraian di atas dan mengingat belum adanya penelitian tentang kualitas air sumur gali Desa Candikuning, Kabupaten Tabanan, maka sangat penting untuk menganalisis adanya kemungkinan pencemaran air sumur akibat perubahan Warna, TDS, dan Kekeruhan pada air sumur yang terdapat di Desa Candikuning.

\section{Metode}

Penelitian ini tergolong penelitian deskritif, yang bertujuan untuk memberikan gambaran mengenai kualitas air sumur ditinjau dari suhu, $\mathrm{pH}$, warna, TDS, dan kekeruhan air sumur. Subjek dalam penelitian ini adalah air sumur di Desa Candikuning, sedangkan objek dalam penelitian ini adalah $\mathrm{pH}$, Suhu, warna, TDS dan kekeruhan. Populasi dalam penelitian ini adalah air sumur gali di Desa Candikuning. Sedangkan sampel dalam penelitian ini adalah air sumur gali yang diambil dengan teknik purposive sampling. Alat yang digunakan dalam pemeriksaan warna dan kekeruhan adalah botol kaca kecil transparan, alat Orbeco Hellige, dan jirigen, sedangkan bahan yang digunakan dalam pemeriksaan warna dan kekeruhan adalah air sumur dan aquades. Alat yang digunakan dalam pemeriksaan untuk uji TDS adalah gelas kimia, dan turbidimeter, sedangkan bahannya adalah air sumur. Data yang didapat dianalisis secara deskriptif. Hasil penentuan warna, kekeruhan, dan TDS air sumur gali dibandingkan dengan nilai parameter warna, kekeruhan dan TDS yang terdapat dalam KEPMENKES No. 907/MENKES/SK/VII/2002 untuk menganalisis apakah warna, kekeruhan dan TDS telah melampaui batas serta apakah air sumur masih layak dikonsumsi sebagai air minum atau tidak, dilihat dari parameter warna, kekeruhan dan TDS.

\section{Hasil dan Pembahasan}

Data hasil pemeriksaan warna, TDS (Total Dissolved Solid), dan kekeruhan air dari contoh air sumur di Desa Candikuning disajikan pada Tabel.1

Tabel 1. Data Pemeriksaan pH, Suhu, Warna, TDS (Total Disolved Solid), dan Kekeruhan Air Sumur di Desa Candikuning Kecamatan Baturiti

\begin{tabular}{llllllll}
\hline No & Nama Dusun & $\mathrm{pH}$ & $\begin{array}{l}\text { Suhu } \\
\left({ }^{0} \mathrm{C}\right)\end{array}$ & $\begin{array}{l}\text { Warna } \\
(\mathrm{TCU})\end{array}$ & $\begin{array}{l}\text { TDS } \\
(\mathrm{mg} / \mathrm{L}\end{array}$ & $\begin{array}{l}\text { Kekeruhan } \\
(\mathrm{NTU})\end{array}$ & $\begin{array}{l}\text { Nilai maksimum yang } \\
\text { masih diperbolehkan } \\
\text { menurut RI No } \\
907 / \mathrm{MENKES} / \mathrm{SK} / \mathrm{VII} / 2002\end{array}$ \\
\hline 1 & Kembang Merta & 7,8 & 31 & 60,8 & 221,7 & 6,1 & 15 \\
2 & Candikuning 2 & 7,8 & 31 & 56,4 & 211,3 & 5,6 & 1000 \\
3 & Candikuning 1 & 7,8 & 31 & 52,7 & 200,8 & 5,0 & 5 \\
\hline
\end{tabular}

Sumber: hasil analisis Laboratorium, 2015

Bahan organik seperti sampah daun dari air sungai, tanin dan bahan yang berasal dari humus dan bahan dekomposisi lignin, dianggap sebagai bahan yang dapat mempengaruhi warna, TDS dan kekeruhan (Sutrisno, 1991; Allaerts dkk, 1984). Dekomposisi bahan organik dipengaruhi oleh $\mathrm{pH}$, suhu, DO (Dissolved Oksigen), jenis bahan organik, serta rasio nitrogen dan karbon. Dari hasil penelitian yang dapat dilihat pada Tabel 1, $\mathrm{pH}$ air sumur di Desa Candikuning saat penelitian adalah 7,8. Sutrisno,1991 menyatakan bahwa kebanyakan mikroorganisme tumbuh pada kisaran $\mathrm{pH}$ 6,0-8,5 dan proses dekomposisi bahan organik belangsung lebih cepat pada $\mathrm{pH}$ netral dan alkalis. Sehingga $\mathrm{pH}$ air sumur di Desa Candikuning mendukung proses dekomposisi bahan organik. Jika dibandingkan dengan KEPMENKES RI No 907/MENKES/SK/VII/2002, pH yang diperoleh masih berada pada rentangan nilai maksimum yang diperbolehkan 
menurut KEPMENKES RI No 907/MENKES/SK/VII/2002 yaitu 6,5-8,0.

$$
\text { Suhu sangat berperan }
$$

mengendalikan kondisi ekosistem

perairan. Peningkatan suhu mengakibatkan penurunan viskositas, reaksi kimia, evaporasi dan volatilitas. Peningkatan suhu juga menyebabkan penurunan kelarutan gas dalam air, misalnya $\mathrm{O}_{2}, \quad \mathrm{CO}_{2}, \quad \mathrm{~N}_{2} \quad \mathrm{CH}_{4}$ dan sebagainya. Selain itu, peningkatan suhu juga menyebabkan peningkatan kecepatan metabolisme dan respirasi organisme air, dan selanjutnya mengakibatkan peningkatan konsumsi oksigen oleh organisme akuatik sekitar 23 kali lipat. Namun, peningkatan suhu disertai dengan penurunan kadar oksigen terlarut sehingga keberadaan oksigen sering kali tidak mampu memenuhi kebutuhan oksigen bagi organisme akuatik untuk melakukan proses metabolisme dan respirasi. Peningkatan suhu juga menyebabkan terjadinya peningkatan dekomposisi bahan organik oleh mikroba (Effendi, 2003; Kodoatie, 1996). Suhu pada penelitian air sumur di Desa Candikuning adalah $31^{\circ} \mathrm{C}$. Suhu tersebut mendukung proses dekomposisi bahan organik. Keadaan ini sesuai dengan pernyataan Sutrisno, 1991 yaitu nilai temperatur yang diperoleh suhu ini, setiap peningkatan suhu sebesar $10^{\circ} \mathrm{C}$ akan meningkatkan proses dekomposisi oksigen menjadi dua kali lipat.

Suhu juga dapat berpengaruh terhadap DO (oksigen terlarut). Hubungan kadar oksigen jenuh dan suhu adalah semakin tinggi suhu, kelarutan oksigen semakin berkurang (Effendi, 2003). Cole, 1998 dalam Effendi, 2003 menyebutkan pada suhu $31^{\circ} \mathrm{C}$ maka DO jenuh adalah $7,43 \mathrm{mg} / \mathrm{L}$. Jadi jika dilhat dari $\mathrm{pH}$, suhu, dan DO jenuh kondisi air sumur di Desa Candikuning memungkinkan terjadinya dekomposisi bahan organik.

$$
\text { Dekomposisi tidak dapat }
$$
berlangsung tanpa nitrogen. Apabila bahan organik mengandung sedikit nitrogen, mikroorganisme justru memanfaatkan nitrogen di perairan. Oleh karena itu, sejumlah nitrogen diperlukan bagi pertumbuhan mikroorganisme, jika bahan organik yang mengalami dekomposisi mengandung banyak nitrogen, maka mikroorganisme nitrogen yang merupakan hasil dekomposisi bahan organik juga dilepas ke perairan. Bahan organik dengan rasio $40 \% \mathrm{C}$ dan $0,5 \% \mathrm{~N}$ akan lebih lambat mengalami dekomposisi daripada bahan organik dengan rasio $40 \%$ C dan $4 \% \mathrm{~N}$.

Penelitian nilai TDS yang terdapat pada sampel air sumur di Desa Candikuning Kabupaten Tabanan adalah $221,7 \mathrm{mg} / \mathrm{L}$. Nilai ini di bawah nilai maksimum yang diperbolehkan untuk standar kualitas air minum yang diatur dalam KEPMENKES RI No 907/MENKES/SK/VII/2002 yaitu 1.000 $\mathrm{mg} / \mathrm{L}$. TDS biasanya disebabkan oleh bahan anorganik yaitu ion-ion yang ada di perairan salah satu contohnya yaitu ion besi. Besi kadang-kadang ada sebagai bahan berasal dari humus (feric-humate) dan menghasilkan warna dengan potensi yang tinggi (Sutrisno, 1991; Franzini dkk, 1991).

Warna dapat disebabkan oleh TDS. Tabel 1 terlihat bahwa warna yang terdapat pada sampel air pada air sumur di Desa Candikuning dan Kecamatan Baturiti Kabupaten Tabanan 60,8 skala TCU. Nilai warna tersebut jauh berada di atas nilai maksimum yang diperbolehkan oleh standar kualitas air minum yang diatur dalam Keputusan Menteri Kesahatan RI No 907/MENKES/SK/VII/2002 yaitu 15 Skala TCU. Warna pada air sumur gali di Desa Candikuning, selain disebabkan oleh bahan-bahan yang tersuspensi juga disebabkan oleh bahan anorganik. Bahanbahan tersuspensi tersebut dikatakan sebagai "apparent color" yang disebabkan oleh kentalan organis atau tumbuhan yang 
biasa hidup di tempat yang lembab. Dengan adanya bahan tersebut, sehingga warna yang tampak pada air sumur di lapangan memberikan warna keputihan dan juga akan menimbulkan kekeruhan pada air sumur gali di Desa Candikuning. Hal tersebut juga didukung oleh Sutrisno, 1991 menyatakan bahwa tingginya nilai kekeruhan pada air karena banyaknya partikel bahan yang tersuspensi, sehingga memberikan warna/rupa yang berlumpur dan kotor. Hal ini juga didukung oleh Effendi, 2003 dan Sastrawijaya, 1991 menyebutkan bahwa kekeruhan di suatu perairan dapat disebabkan oleh bahan organik dan anorganik yang tersuspensi dan terlarut (misalnya lumpur dan pasir halus), maupun bahan anorganik dan organik yang berupa plankton dan mikroorganisme.

Padatan tersuspensi berkorelasi positif dengan kekeruhan. Semakin tinggi nilai padatan tersuspensi, nilai kekeruhan juga semakin tinggi. Sehingga hal tersebutlah yang menyebabkan terdapatnya kekeruhan yang melebihi standar yang ditetapkan. Nilai kekeruhan saat penelitian disajikan pada Tabel 1 adalah 6,1 skala NTU dan nilai ini berada di atas nilai maksimum yang diperbolehkan oleh standar kualitas air minum yang diatur dalam Keputusan Menteri Kesehatan RI No 907/MENKES/SK/VII/2002 yaitu 5 Skala NTU. Tingginya nilai kekeruhan dapat menimbulkan kekhawatiran terkandungnya bahan-bahan kimia yang dapat mengakibatkan efek toksik terhadap manusia. Walaupun semakin tinggi nilai padatan tersuspensi, nilai kekeruhan juga semakin tinggi, tetapi tingginya nilai kekeruhan tidak selalu diikuti dengan tingginya padatan terlarut (TDS). Maka jika dilihat dari nilai TDS pada saat penelitian tidak melampaui nilai maksimum yang diperbolehkan untuk standar kualitas air minum yang diatur dalam KEPMENKES RI No
907/MENKES/SK/VII/2002 sedangkan nilai kekeruhan pada saat penelitian berada di atas nilai maksimum yang diperbolehkan oleh standar kualitas air minum.

Nilai warna dan kekeruhan pada air sumur di Desa Candikuning sangat melebihi batas maksimum yang diperbolehkan, sehingga jika dilihat dari nilai warna dan kekeruhannya, air sumur tersebut kurang layak untuk dikonsumsi sebagai air minum. Walaupun demikian karena air merupakan kebutuhan vital dan air sumur tersebut merupakan sumber air yang paling murah di sekitar Desa Candikuning, sehingga air sumur tersebut tetap dimanfaatkan. Oleh karena itu perlu adanya pengolahan terhadap air sumur sebelum dimanfaatkan.

\section{Kesimpulan}

Berdasarkan hasil penelitian dan pembahasan yang telah dipaparkan di atas maka hal-hal dapat disimpulkan sebagai berikut. Pertama, nilai kadar warna, TDS, dan Kekeruhan pada air sumur di Desa Candikuning Kecamatan Baturiti Kabupaten Tabanan dilakukan secara pengulangan adalah warna 60,8 Skala TCU, TDS (Total Disolved Solid) 221,7 mg/L, dan kekeruhan 6,1 Skala NTU. Kedua, kualitas air sumur di Desa Candikuning Kabupaten Tabanan kurang layak dikonsumsi sebagai air minum dilihat dari nilai warna, TDS, dan kekeruhan, berdasarkan standar kualitas air minum menurut Keputusan Menteri Kesehatan RI No 907/MENKES/SK/VII/2002. Berdasarkan hasil penelitian dan pembahasan di atas maka penulis menyarankan agar kualitas air sumur di Desa Candikuning Kecamatan Baturiti Kabupaten Tabanan sebaiknya dipantau secara periodik untuk mengetahui tingkat kelayakan air sumur tersebut sesuai dengan peruntukannya. Sebaiknya dilakukan penelitian lebih lanjut dengan menambah parameter-parameter 
lain sesuai dengan Keputusan Menteri

Kesehatan RI No

907/MENKES/SK/VII/2002, sehingga akan dapat menggambarkan kualitas air sumur tersebut dengan jelas. Sebelum air sumur dikonsumsi sebaiknya melakukan perebusan terlebih dahulu dan penyaringan untuk meminimalkan bakteri dan bahan-bahan terlarut pada air sumur yang menyebabkan efek negatif pada masyarakat.

\section{Daftar Pustaka}

Allaerts, $G$ dan Sri Sumestri Santika. 1984.Metode Penelitian air. Surabaya: Usaha Nasional.

Effendi Hefni. 2003. Telaah Kualitas Air. Yogyakarta: Kanisius.

Franzini, Joseph B dan Ray K. Linseley. 1991. Teknik Sumber Daya Air. Edisi ketiga. Jakarta: Erlangga.
Keputusan Mentri Negara Lingkungan Hidup No. 02/MENKELH Tahun 1988 Tentang Kependudukan dan Lingkungan Hidup.

Kodoatie Robert.J. 1996. Pengantar Hidrogeologi. Yogyakarta: ANDI.

Peraturan Mentri Kesehatan Republic Indonesia No.

907/MENKES/SK/VII/2002

Tentang Syarat-Syarat dan Pengawasan Air Minum.

Sastrawijaya Tresna. 1991. Pencemaran Lingkungan. Surabaya. Rineka Cipta.

Sutrisna Toto. 1991. Teknologi Penyediaan Air Bersih. Jakarta: Rineka Cipta. 